\title{
Anestesi til barn
}

\author{
Sammendrag \\ Bakgrunn. Barneanestesi omfatter \\ anestesi til nyfødte, spedbarn og større \\ barn.
}

Materiale og metode. Denne oversikten er bygd på lærebøker innen barneanestesi, et skjønnsmessig utvalg av artikler fra sentrale anestesitidsskrifter og erfaringer fra mangeårig klinisk arbeid.

Resultater. De fleste anestesileger i Norge bedøver både voksne og barn. Bare ved enkelte universitetssykehus finnes det anestesileger som kun driver med barneanestesi. Anestesirelatert sykelighet og dødelighet er høyere hos små barn enn hos voksne, og larynxspasme og oppvåkningsdelirium forekommer hyppigere. Metoder som narkoseinnledning med gass på maske og sakralbedøvelse benyttes oftere til barn. Vektbasert utregning av medikamentdoser og intravenøs væsketilførsel er nødvendig. Sykdommer og medfødte misdannelser kan medføre anestesiologiske problemer, det er derfor viktig at anestesilegen får opplysninger om dette preoperativt.

Fortolkning. Barneanestesi innebærer spesielle utfordringer. Sikker gjennomføring krever erfaring og kunnskap om aldersavhengig anatomi, fysiologi og patologi.

\section{Gro Østgaard}

gro.ostgaard@helse-bergen.no Atle Ulvik

Kirurgisk serviceklinikk

Haukeland universitetssykehus 5021 Bergen

Moderne anestesi er forbundet med svært liten risiko for død og alvorlige komplikasjoner. Det er imidlertid vanskelig å angi konkrete tall for sykelighet og dødelighet. En undersøkelse fra Frankrike i 1999 viste en forekomst på ca. ett dødsfall per 100000 anestesier hos barn under 15 år (1). Sammenliknet med franske data fra ti år tidligere var mortaliteten betydelig redusert (2). Nyfødte og spedbarn har høyere risiko for anestesirelatert sykelighet og dødelighet enn større barn og unge voksne $(3,4)$. I en studie fra 1988 ble det registrert 4,3 livstruende komplikasjoner per 1000 anestesier hos barn under ett år (3).

Luftveishåndtering har tradisjonelt vært ansett som det mest risikofylte ved barneanestesi. Tall fra en amerikansk database angående hjertestans under anestesi viser at store peroperative blødninger hos små barn er et økende problem (4) - risikoen er dermed i hovedsak relatert til det kirurgiske inngrepet. Som for voksne gjelder at sykdom og hastegrad påvirker risikoen, men selv ved anestesi hos friske barn i forbindelse med planlagte, mindre inngrep og undersøkelser kan det skje ulykker. Enhver beslutning om å bedøve et barn må derfor være nøye gjennomtenkt.

I denne artikkelen vil vi belyse noen av årsakene til at barneanestesi byr på spesielle utfordringer. Vanlige rutiner der hensikten er å redusere risikoen og gjøre det perioperative forløpet best mulig for både barnet og foreldrene blir omtalt.

\section{Materiale og metode}

Materialet til denne oversikten er lærebøker innen barneanestesi og et skjønnsmessig utvalg artikler fra sentrale anestesitidsskrifter. Forfatterne har mange års erfaring fra klinisk arbeid.

\section{Organisering av barneanestesi i Norge}

For å bli godkjent spesialist $\mathrm{i}$ anestesiologi i Norge kreves det at man skal ha gjennomført minst 200 anestesier hos barn under ti år, herunder minimum ti hos barn under ett år og 40 hos barn i alderen 1-5 år (5). Anestesileger velger ofte sideutdanning ved en barneavdeling, men mange ønsker seg nok mer erfaring med barneanestesi enn det de får under spesialiseringen.

Ved Oslo universitetssykehus (Rikshospitalet og Ullevål) og St. Olavs hospital finnes det spesialister som kun bedøver barn, men de fleste barneanestesier her i landet utføres av anestesileger som behandler både barn $\mathrm{og}$ voksne. Det er allmenn enighet om at anestesi til spedbarn krever en viss kompetanse og regelmessig praktisering, men det foreligger ingen formelle retningslinjer utover spesialistgodkjenningen. Barneanestesilegeforeninger $\mathrm{i}$ andre europeiske land har foreslått at ett av kravene til dem som har ansvar for de minste, er at de bedøver barn minst en halv dag per uke (6). Dette kan tjene som veiledning for sykehusadministratorer og anestesileger med tanke på hvilke oppgaver man skal påta seg. I tillegg til kompetent anestesipersonell kreves også lokaliteter og spesialutstyr som er egnet for barn. Hvis det bedøves både voksne og barn på samme operasjonsstue, bør barna samles på egne dager. Det bør også være en egen postoperativ overvåkingsenhet for barn.

\section{Anatomi og fysiologi}

Anatomi og fysiologi kan forklare det meste av den økte risikoen forbundet med anestesi hos de små. Ett eksempel er forholdet mellom oksygenreserver og oksygenforbruk. Små barn har et høyt oksygenforbruk, men relativt små oksygenlagre. Hos en frisk voksen som veier $70 \mathrm{~kg}$ faller oksyhemoglobinmetningen til $85 \%$ etter en apnéperiode på 84 sekunder, mens et barn på $10 \mathrm{~kg}$ får det samme metningsfallet i løpet av 41 sekunder (7). Det betyr at man har kort tid på seg til å etablere en sikker luftvei når barnet slutter å puste $\mathrm{i}$ forbindelse med innledning av anestesi.

\section{Hovedbudskap}

- Den anestesirelaterte sykelighet og dødelighet er lav. Risikoen er høyest hos de minste barna

- Risikoreduksjon krever kunnskap, erfaring og god forberedelse

- Nøye planlegging og overvåking av væske-, smerte- og kvalmebehandling er viktig for et godt resultat 
Nyfødte har lungevev med liten elastisitet og en myk brystvegg som er avhengig av muskeltonus for å opprettholde volum og dermed funksjonell residualkapasitet. Dette øker faren for atelektasedanning og hypoksi under anestesi. Hos barn under seks måneder er ventilasjonen dominert av diafragma (8). Fylles magesekken med luft, enten under maskeventilasjon eller ved gastroskopi, kan det føre til store problemer med ventilasjonen. Luftveiene hos barn har små dimensjoner, og et slimhinneødem i trachea, for eksempel etter bruk av en for stor trakealtube, vil kunne redusere lumen dramatisk.

Hos nyfødte er det også spesielle sirkulasjonsfysiologiske forhold man må ta hensyn til. Hjerteminuttvolumet bestemmes i stor grad av hjertefrekvensen fordi myokard hos de minste har nedsatt Frank-Starling-respons og dermed begrenset mulighet til å øke hjertets slagvolum.

Det er normalt høy forekomst av apnéperioder hos premature (barn født før uke 37). Disse kan forverres av generell anestesi helt opp til en alder som tilsvarer 60 . gestasjonsuke (9). Hvis mulig bør man vente med anestesi til barnet har nådd det som tilsvarer uke 46. Alle tidligere premature som er yngre enn dette overvåkes nøye med henblikk på pustestopp i minst 12 timer etter inngrepet. Disse barna er derfor ikke egnet for dagkirurgisk virksomhet.

\section{Anestesiologisk preoperativ vurdering}

Det er viktig å være forberedt før en anestesi, det gjelder både anestesipersonalet, pasienten og de pårørende. Hensikten med anestesilegens preoperative samtale med foreldre og barn er å skaffe til veie opplysninger om barnet og informere om planlagt anestesi. Med dagens effektiviserte pasientbehandling finner mange slike samtaler sted på innledningsrommet operasjonsdagen. Det ideelle hadde vært noen dager på forhånd.

Hvilke opplysninger trenger anestesilegen? Anestesilegen må ha opplysninger om tidligere sykehistorie, faste medisiner og allergier, generell organstatus, vekt og løse tenner. Det kan være nødvendig å rekvirere ytterligere undersøkelser, søke i litteraturen eller rådføre seg med kolleger. Leger som henviser til sykehusets poliklinikker, har et stort ansvar for å opplyse om tilleggslidelser. Blodprøver tas som regel bare på indikasjon. Måling av hemoglobinnivå, blodtyping og antistoffscreening gjøres hvis det kirurgiske inngrepet medfører blødningsrisiko.

\section{Informasjon}

God informasjon kan skape trygghet og forebygge angst. Mange sykehus har laget brosjyrer og Internett-basert informasjon beregnet på både barn og pårørende. Det er viktig at foreldre eller andre som skal følge barnet, er forberedt på hva som vil møte dem på operasjonsstuen. Innledning av anestesi kan foregå enten på operasjonsbordet eller ved at barnet sitter på fanget til en voksen. Når narkosen innledes med intravenøse midler, er overgangen fra et våkent barn til et slapt, bevisstløst barn svært rask, og dette kan virke skremmende. Ved innledning med inhalasjonsmiddel via maske er det vanlig at barnet går gjennom en fase med motorisk uro. Dette bør man også opplyse om på forhånd.

\section{Preoperativ faste}

Preoperativ faste er viktig for å unngå aspirasjon av mageinnhold til luftveiene under anestesi. Det er samme fasterutiner for både voksne og barn. Barnet kan drikke saft og vann inntil to timer før anestesi og kan ammes eller få morsmelkerstatning inntil fire timer før. Fast føde eller melk må ikke inntas de siste seks timene preoperativt.

\section{Premedikasjon}

Behov for beroligende medisin, premedikasjon, før anestesi avklares på previsitten. Ved mange dagkirurgiske enheter har man valgt ikke å gi premedikasjon og synes dette fungerer greit. Generelt er behovet størst hos barn i alderen 6 md. -6 år. Engstelige barn og barn som er blitt skremt av tidligere møter med helsevesenet, bør få premedikasjon. Benzodiazepinet midazolam er mest brukt. Injeksjonsløsningen gitt rektalt eller peroralt blandet i litt saft, i en dose på $0,5 \mathrm{mg} / \mathrm{kg}$ (maksimalt 12,5 mg), virker i løpet av 5-10 minutter, og etter 20-30 minutter er virkningen maksimal. Barnet er vanligvis tydelig sedert, men våken og medgjørlig. Midazolam gir amnesi, noe foreldrene bør gjøres oppmerksom på.

Alle som skal ha venekanyle, bør få lokalbedøvende krem eller plaster (Emla) over synlige vener, gjerne på to steder, minst én time før planlagt anestesi.

\section{Luftveisinfeksjoner}

Luftveisinfeksjoner øker risikoen for komplikasjoner som larynxspasme, stridor og bronkospasme. Derfor bør elektiv kirurgi utsettes i 1-2 uker dersom barnet er forkjølet med feber og nedsatt allmenntilstand, grønn snørr og produktiv hoste. Ved mindre symptomer blir det en vurderingssak hvor alder, tidligere sykehistorie med for eksempel astma og inngrepets art teller med. Nedre luftveisinfeksjoner og spesielt bronkiolitt forårsaket av RS-virus medfører langvarig hyperreaktivitet i luftveiene. Operasjoner som kan vente, bør derfor utsettes i minst seks uker (10).

Vaksinasjon er ingen kontraindikasjon mot anestesi, men der en vaksinereaksjon kan vanskeliggjøre diagnostisering av eventuelle postoperative komplikasjoner, anbefales det å utsette operasjonen i noen dager.

\section{Kardiale bilyder}

Fysiologiske bilyder er vanlig hos barn. Barn med bilyd henvises til ekkokardiografi før anestesi etter de samme retningslinjer som gjelder for barn generelt (11). Kort oppsummert bør de med bilyder av styrke $\geq 3$ av 6 , holosystoliske og -diastoliske bilyder og bilyder som er hørbare på ryggen henvises til barnekardiolog. Der det er klinisk mistanke om hjertesykdom, bør barnet også henvises, det gjelder også alle med syndromer og bilyd.

\section{Alvorlig syke barn}

Anestesi hos barn med medfødte misdannelser og alvorlige sykdommer krever ekstra forberedelser. Å sette seg inn i en komplisert sykehistorie kan ta lang tid. Informasjon om tidligere anestesier er viktig og må være tilgjengelig.

Syndromer som innebærer vanskelig luftveistilgang er en stor utfordring for anestesilegen, og her må man planlegge godt på forhånd. Selv ved universitetssykehusene er det kanskje bare én eller to anestesileger med spesialkompetanse på området. Elektiv kirurgi bør foregå når disse er til stede.

Ved nevromuskulære sykdommer må man ta spesielle hensyn ved valg av anestesimidler (12). Barn som utredes med muskelbiopsi med tanke på muskeldystrofi, kan utvikle en livstruende hyperkalemi hvis de får det muskelavslappende midlet suksinylkolin.

I Norge opereres medfødte hjertefeil kun ved Rikshospitalet. Anestesileger ellers i landet får derfor begrenset erfaring med «hjertebarn». Når disse barna skal bedøves for andre operasjoner ved andre sykehus, er det viktig at legen får tid til å sette seg inn i fysiologien på forhånd for å kunne forutse mulige problemer perioperativt. For barn med alvorlige ukorrigerte eller delvis korrigerte hjertefeil kan det være aktuelt at all type kirurgi og alle undersøkelser i narkose foretas ved Rikshospitalet. Eksempel er pasienter med vitier, der anestesi og overtrykksventilasjon kan bidra til økt lungekarmotstand slik at en høyre-til-venstre-shunt blir kritisk.

Hos multihandikappede er det ofte et ønske om å gjøre flere mindre inngrep og undersøkelser i samme narkose. I noen tilfeller er det mulig, men ofte vil det være tryggere og enklere å gi flere korte anestesier.

Barn med kreft kan trenge tallrike anestesier for prøvetaking og behandling. Forberedelsene er da ekstra viktige for å skape trygghet for barn og foreldre.

\section{Anestesi ved øyeblikkelig hjelp}

Anestesi til ikke-fastende medfører økt fare for aspirasjon til luftveiene. Små barn trenger ofte generell anestesi til prosedyrer som hos voksne kan gjøres uten bedøvelse eller i lokalanestesi. Det er viktig at barn som sendes til sykehus med tilstander der anestesi kan bli nødvendig, ikke får mat. Røntgenundersøkelser kan ofte gjennomføres med midazolamsedering, mens smertefulle prosedyrer som regel krever narkose. «En liten rus» kan i denne sammenhengen være en 
farlig løsning som kan føre til aspirasjon av mageinnhold til lungene og påfølgende alvorlige komplikasjoner.

Hvis det er mulig å utsette prosedyren, kan man vente seks timer i påvente av at barnet skal bli fastende, men graden av ventrikkeltømming vil alltid være usikker, spesielt ved smerter og behov for opioider. Anestesileger vil da ofte velge å intubere barnet for å sikre mot aspirasjon der man ellers ville kunne bruke enklere luftveishåndteringer.

Ketamin er et alternativ ved smertefulle prosedyrer av kort varighet, for eksempel fjerning av fremmedlegeme, mindre suturering og enkle reponeringer. Dette er et anestesimiddel som gir god analgesi og søvn, selv om øynene kan forbli åpne og muskeltonus er til stede. Egenrespirasjon og beskyttende reflekser i svelget er bevart, men spyttsekresjonen kan øke og føre til luftveisirritasjon og larynxspasme.

Studier med ikke-fastende barn i traumemottak bedøvet med ketamin og midazolam uten intubasjon viste ingen økt forekomst av aspirasjon (13). Det er viktig å presisere at dette er en anestesi som krever tilstedeværelse av anestesikyndig personale. Lokalbedøvende krem eller plaster på stedet for planlagt venekanyle og premedikasjon er spesielt nyttig i øyeblikkelig hjelp-situasjoner, da barnet ofte er skremt av forutgående hendelser.

\section{Gjennomføring av anestesi}

I dag er det en selvfølge at barn som skal få anestesi, har med seg foreldre/foresatte. Den voksne er med under innledningen og følges ut etter at barnet har sovnet. Ved Haukeland universitetssykehus er hovedregelen at bare én person er med inn på operasjonsstuen. De under seks måneder har ikke samme separasjonsangst som eldre barn og ledsages derfor vanligvis ikke av foreldrene inn på stuen.
Innledningen gjøres som regel med intravenøse anestesimidler. I tillegg til barbituratet tiopental er propofol mye brukt, selv om det kan gi smerte ved injeksjon. Narkoseinnledningen kan også gjøres med anestesigass via maske. Dette er et godt alternativ hvis det er vanskelig å få etablert intravenøs tilgang. Det er lettere å legge inn venekanyle på et sovende barn. Vedlikehold av anestesien gjennomføres med gass ellerfra en måneds alder - med propofol på pumpe og skiller seg lite fra prosedyren hos voksne.

\section{Peroperativ væskebehandling}

Under operasjonen tilføres isotone eller lett hypotone elektrolyttløsninger (f.eks. Ringer-acetat) intravenøst for å dekke basalt væskebehov og erstatte underskudd på grunn av faste og pågående tap. Det er sjelden behov for glukose peroperativt, men nyfødte, barn som har fastet lenge, barn med mitokondriesykdom og barn som har fått glukose intravenøst like før operasjonen, trenger ofte glukose også under operasjonen. Behovet for tilførsel av glukose bør monitoreres ved hjelp av blodsukkermåling.

\section{Regionalanestesi}

Hos barn er regionalanestesi oftest et supplement til generell anestesi. Hensikten er smertelindring både peroperativt og særlig postoperativt. Et unntak er spinal- eller sakralbedøvelse til premature som skal opereres for lyskebrokk (fig 1). Spinalbedøvelse gitt alene øker ikke frekvensen av apné hos disse barna på samme måte som generell anestesi (9). Bronkopulmonal dysplasi styrker indikasjonen for regionalanestesi. Spinalanestesi hos nyfødte har kort virketid, 1-1,5 timer, og et godt samarbeid med kirurgen er en forutsetning for at dette skal fungere.

Sakralbedøvelse er en enkel form for

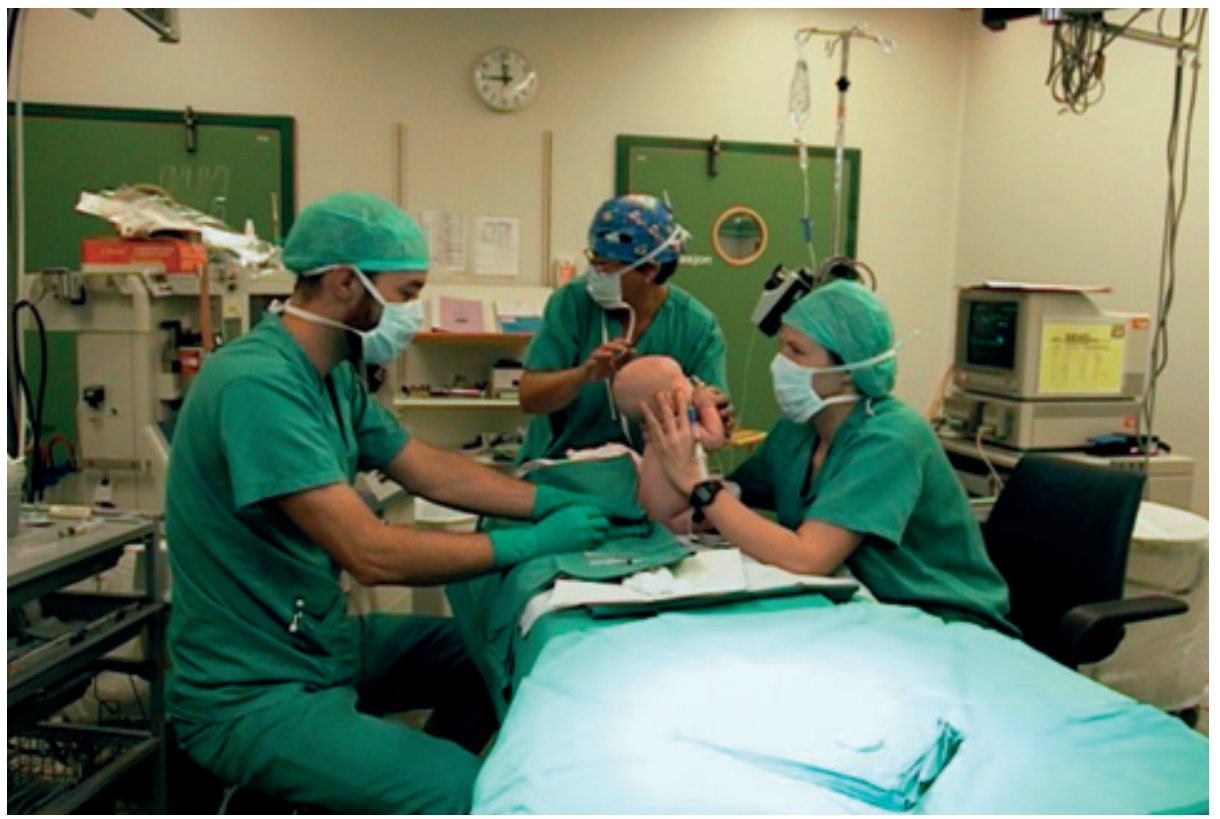

Figur 1 Anlegging av spinalanestesi hos nyfødt epiduralbedøvelse og brukes ved inngrep nedenfor navlen. Andre eksempler på alminnelige regionalanestimetoder til barn er penisblokade ved fimoseoperasjoner, femoralisblokade ved femurfrakturer og bedøvelse av plexus brachialis ved armbrudd.

\section{Larynxspasme}

Komplikasjonen larynxspasme forekommer hos voksne, men er hyppigere ved anestesi til barn. Dette er en reflektorisk utløst, potensielt livstruende spasme i larynxmuskulaturen som umuliggjør luftpassasje (14). Larynxspasme kan forekomme både under innledning og vedlikehold av anestesi, men er vanligst $\mathrm{i}$ forbindelse med oppvåkning og er ofte utløst av sekret på stemmebåndene etter at trakealtuben er fjernet. En undersøkelse fra Sverige viste en frekvens på 17 per 1000 anestesier til barn under ti år (15). Det er en vanlig oppfatning at frekvensen er lavere med erfarent anestesipersonell. Tilstanden kan som regel effektivt behandles med oksygen på maske med moderat overtrykk, men av og til må man gi suksinylkolin for å få spasmen til å løsne (14).

\section{Postoperative tiltak}

\section{Smerte}

Postoperativ smertebehandling bør planlegges før operasjonen. Hos ellers friske barn over tre måneder er det vanlig å gi paracetamol peroralt eller rektalt $-80-100 \mathrm{mg} / \mathrm{kg}$ operasjonsdøgnet fordelt på fire doser (16, 17). Peroral administrering foretrekkes på grunn av raskere og mer forutsigbar absorpsjon såfremt ventrikkeltømmingstiden er normal. Maksimal serumkonsentrasjon etter suppositorier kommer først etter 1,5-2 timer, og ved korte inngrep må disse derfor gis før operasjonen. Nylig ble paracetamol til intravenøst bruk (Perfalgan) også godkjent til nyfødte.

Ifølge Felleskatalogen er ibuprofenmikstur eneste ikke-steroide antiflogistikum registrert til små barn, mens diklofenak suppositorier kan brukes fra seks års alder. I England er diklofenak godkjent allerede fra seks måneders alder (16). Vi bruker diklofenak stikkpiller på 12,5 mg til barn over 12 måneder.

Ved behov for sterkere analgetika er morfin førstevalget. Morfin gis intravenøst, enten som titrerte enkeltdoser eller som kontinuerlig infusjon. Fra seks års alder er pasientkontrollert administrasjon et alternativ. Regionalanestesi og perifere nerveblokader er også mye brukt for å redusere postoperativ smerte.

\section{Kvalme og oppkast}

Forekomsten av oppkast postoperativt øker fra tre års alder og rammer ca. $30 \%$. Ved enkelte kirurgiske inngrep, for eksempel strabismeoperasjoner, er det økt risiko. En nylig Cochrane-gjennomgang av forebyggende behandling ved postoperativ kvalme og oppkast konkluderte med at ondansetron var mer effektivt hos barn enn hos voksne, mens 
effekten av øvrige antiemetika ikke varierte med alderen (18). Barn med høy risiko for oppkast postoperativt bør få kvalmeprofylakse. Ondansetron er da førstevalget, eventuelt kombinert med steroider, droperidol og metoklopramid.

\section{Væskebehandling}

Postoperativ væskebehandling hos barn har vært hyppig debattert i pediatriske og anestesiologiske tidsskrifter. Etter mindre inngrep hvor barnet kan begynne å drikke i løpet av få timer, er det ikke nødvendig med intravenøs væsketilførsel postoperativt. I 1990 rapporterte Kongsgaard og medarbeidere om en fem år gammel gutt med alvorlig hyponatremi og kramper etter tilførsel av kun $5 \%$ glukoseløsning under og etter en tonsillektomi (19).

Øt utskilling av antidiuretisk hormon etter kirurgiske inngrep kan føre til vannretensjon, og tilførsel av glukoseløsning vil øke faren for hyponatremi. Velger man glukose som væskebehandling til små barn postoperativt, må derfor serum-elektrolyttkonsentrasjoner kontrolleres nøye. Hvis dette ikke kan gjennomføres, er det tryggere å gi en blandingsløsning med natriumklorid og glukose.

\section{Oppvåkningsdelirium}

Akutt, forbigående uro etter anestesi, også kalt oppvåkningsdelirium, er ikke uvanlig hos barn. Det forekommer hyppigst i førskolealderen. Tilstanden kjennetegnes ved et fullstendig oppkavet barn som ikke lar seg trøste eller avlede av foreldrene. Årsaken er ukjent. Etter operasjoner vil det ofte kunne være usikkerhet om barnets uro skyldes smerter, men oppvåkningsdelirium ses også etter anestesi i forbindelse med prosedyrer uten smertestimulering, for eksempel røntgenundersøkelser.
Anestesigassen sevofluran gir høyest frekvens av postoperativ agitasjon, men per $i$ dag er det ingen anestesiformer, premedikasjon eller medikamenter som helt kan forhindre denne tilstanden (20). Foreldre til førskolebarn bør informeres på forhånd om at dette kan opptre etter anestesi og at tilstanden går over av seg selv i løpet av 30-60 minutter. En liten dose intravenøst anestesimiddel kan brukes i de tilfellene det er behov for tiltak.

\section{Oppsummering}

Anestesirelatert sykelighet og dødelighet er høyere hos små barn enn hos voksne. Sikker gjennomføring av barneanestesi krever kunnskap og erfaring, kjennskap til barnet som skal bedøves og god planlegging. Nøye overvåking av væske-, smerte- og kvalmebehandling er viktig for et godt resultat. God informasjon kan skape trygghet og forebygge angst hos både barn og foreldre.

Oppgitte interessekonflikter: Ingen

\section{Litteratur}

1. Lienhart A, Auroy Y, Péquignot F et al. Survey of anesthesia-related mortality in France. Anesthesiology 2006; 105: 1087-97.

2. Tiret $L$, Nivoche $Y$, Hatton $F$ et al. Complications related to anaesthesia in infants and children. Br J Anaesth 1988; 61: 263-9.

3. Murat I, Constant I, Maud'huy H. Perioperative anaesthetic morbidity in children: a database of 24165 anaesthetics over a 30-month period. Pediatr Anesth 2004: 14: 158-66.

4. Bhananker SM, Ramamoorthy C, Geiduschek JM et al. Anesthesia-related cardiac arrest in children: update from the pediatric perioperative cardiac arrest registry. Anesth Analg 2007; 105: $344-50$.

5. Den norske legeforening. Sjekkliste for spesialiteten anestesiologi. www.legeforeningen.no/ (12.11.2008).

6. Federation of European Associations of Pediatric Anaesthesia. European guidelines for training in paediatric anaesthesia. www feapa sm pl/ (12.11.2008).

7. Farmery AD, Roe PG. A model to describe the rate of oxyhaemoglobin desaturation during apnoea. Br J Anaesth 1996: 76:284-91.

8. Motoyama EK. Respiratory physiology in infants and children. I: Motoyama EK, Davis PJ, red. Smith's Anesthesia for infants and children. 7. utg Saint-Louis, MO: Mosby-Elsevier, 2006: 12-69.

9. Walther-Larsen S, Rasmussen LS. The former preterm infant and risk of post-operative apnoea: recommendations for management. Acta Anaesthesiol Scand 2006; 50: 888-93.

10. Tait AR, Malviya S. Anesthesia for the child with an upper respiratory tract infection: still a dilemma? Anesth Analg 2005; 100: 59-65.

11. Berg A, Greve G, Hirth A et al. Vurdering av barn med hjertebilyder. Tidsskr Nor Lægeforening 2005: 125: 1000-3.

12. Ross AK. Muscular dystrophy versus mitochondrial myopathy: the dilemma of the undiagnosed hypotonic child. Pediatr Anaesth 2007; 17: 1-6.

13. Roback MG, Bajaj L, Wathen JE et al. Preprocedual fasting and adverse events in procedual sedation and analgesia in a pediatric emergency department: are they related? Ann Emerg Med 2004; 44 454-9.

14. Holzki J. Airway obstruction: causes and management. I: Sumner E, Hatch DJ, red. Paediatric Anaesthesia. London: Arnold, 1999: 479-507.

15. Olsson GL, Hallen B. Laryngospasm during anaesthesia. A computer-aided incidence study in 136 929 patients. Acta Anaesthesiol Scand 1984: 28: 567-75.

16. Howard R, Carter B, Curry J et al. Section 6. Analgesia review. Pediatr Anesth 2008; 18: 64-78.

17. Rygnestad T, Spigset 0 . Bruk av paracetamol til barn. Tidsskr Nor Lægeforening 2001; 121: 708-9.

18. Carlisle JB, Stevenson CA. Drugs for preventing postoperative nausea and vomiting. Cochrane Database Syst Rev 2006; 3.DOI: 10.1002/14651858. www.cochrane.org/reviews/en/ab004125.html (7.5.2009).

19. Kongsgaard UE, Holst-Larsen H, Lie B et al. Uttalt, symptomgivende hyponatremi. Tidsskr Nor Lægeforening 1990; 110: 3617-9

20. Vlajkovic GP, Sindjelic RP. Emergence delirium in children: many questions, few answers. Anesth Analg 2007; 104: 84-91.

Manuskriptet ble mottatt 21.11. 2008 og godkjent 7.5. 2009. Medisinsk redaktør Michael Bretthauer. 